2009-06

\title{
Predicting global habitat suitability for stony corals on seamounts
}

Tittensor, DP

http://hdl.handle.net/10026.1/1415

10.1111/j.1365-2699.2008.02062.x

Journal of Biogeography

Wiley

All content in PEARL is protected by copyright law. Author manuscripts are made available in accordance with publisher policies. Please cite only the published version using the details provided on the item record or document. In the absence of an open licence (e.g. Creative Commons), permissions for further reuse of content should be sought from the publisher or author. 


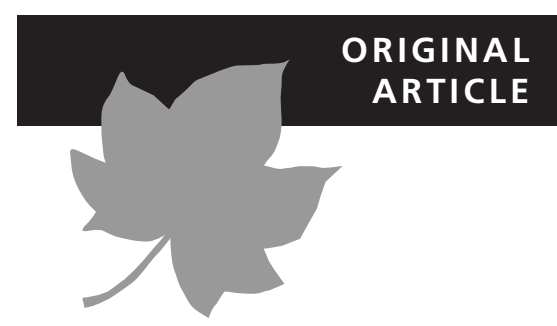

\title{
Predicting global habitat suitability for stony corals on seamounts
}

\author{
Derek P. Tittensor ${ }^{1,2 *}$, Amy R. Baco ${ }^{3}$, Paul E. Brewin ${ }^{4}$, Malcolm R. Clark ${ }^{5}$, \\ Mireille Consalvey ${ }^{5}$, Jason Hall-Spencer ${ }^{6}$, Ashley A. Rowden ${ }^{5}$, Thomas \\ Schlacher ${ }^{7}$, Karen I. Stocks ${ }^{4}$ and Alex D. Rogers ${ }^{2}$
}

${ }^{1}$ Department of Biology, Dalhousie University, Halifax, NS, Canada, ${ }^{2}$ Institute of Zoology, Zoological Society of London, Regent's Park, London, UK, ${ }^{3}$ Department of Oceanography, Florida State University, Tallahassee, FL, USA, ${ }^{4}$ San Diego Supercomputer Center, University of California San Diego, La Jolla, CA, USA,

${ }^{5}$ National Institute of Water and Atmospheric Research, Kilbirnie, Wellington, New Zealand, ${ }^{6}$ Marine Institute, University of Plymouth, Plymouth, UK and ${ }^{7}$ Faculty of Science, Health and Education, University of the Sunshine Coast, Maroochydore, Qld, Australia
${ }^{*}$ Correspondence: Derek P. Tittensor, Department of Biology, Dalhousie University, Life Sciences Centre, 1355 Oxford Street, Halifax, NS B3H 4J1, Canada.

E-mail: derekt@mathstat.dal.ca

\begin{abstract}
Aim Globally, species distribution patterns in the deep sea are poorly resolved, with spatial coverage being sparse for most taxa and true absence data missing. Increasing human impacts on deep-sea ecosystems mean that reaching a better understanding of such patterns is becoming more urgent. Cold-water stony corals (Order Scleractinia) form structurally complex habitats (dense thickets or reefs) that can support a diversity of other associated fauna. Despite their widely accepted ecological importance, records of scleractinian corals on seamounts are patchy and simply not available for most of the global ocean. The objective of this paper is to model the global distribution of suitable habitat for stony corals on seamounts.
\end{abstract}

Location Seamounts worldwide.

Methods We compiled a database containing all accessible records of scleractinian corals on seamounts. Two modelling approaches developed for presence-only data were used to predict global habitat suitability for seamount scleractinians: maximum entropy modelling (Maxent) and environmental niche factor analysis (ENFA). We generated habitat-suitability maps and used a crossvalidation process with a threshold-independent metric to evaluate the performance of the models.

Results Both models performed well in cross-validation, although the Maxent method consistently outperformed ENFA. Highly suitable habitat for seamount stony corals was predicted to occur at most modelled depths in the North Atlantic, and in a circumglobal strip in the Southern Hemisphere between $20^{\circ}$ and $50^{\circ} \mathrm{S}$ and shallower than around $1500 \mathrm{~m}$. Seamount summits in most other regions appeared much less likely to provide suitable habitat, except for small near-surface patches. The patterns of habitat suitability largely reflect current biogeographical knowledge. Environmental variables positively associated with high predicted habitat suitability included the aragonite saturation state, and oxygen saturation and concentration. By contrast, low levels of dissolved inorganic carbon, nitrate, phosphate and silicate were associated with high predicted suitability. High correlation among variables made assessing individual drivers difficult.

Main conclusions Our models predict environmental conditions likely to play a role in determining large-scale scleractinian coral distributions on seamounts, and provide a baseline scenario on a global scale. These results present a firstorder hypothesis that can be tested by further sampling. Given the high vulnerability of cold-water corals to human impacts, such predictions are crucial tools in developing worldwide conservation and management strategies for seamount ecosystems.

\section{Keywords}

Conservation biogeography, distribution, ENFA, habitat suitability, maximum entropy, modelling, niche, Scleractinia, seamount, stony coral. 


\section{INTRODUCTION}

The oceans provide more than $90 \%$ of the habitable area for life on Earth, and $88 \%$ beyond the continental shelves are deeper than $1000 \mathrm{~m}$ (Gjerde, 2006). Most of the current knowledge concerning marine life is confined to coastal ecosystems, the continental shelves and shallow, sunlit waters $(<200 \mathrm{~m}$ depth). The deep sea remains the most poorly sampled ecosystem on the planet (Glover \& Smith, 2003), and only an estimated $0.0001 \%$ of the deep-sea floor has been subject to scientific investigation (Gjerde, 2006). It is therefore not surprising that patterns of benthic diversity and distribution are not well resolved for deep-sea species (Gage, 2004), particularly at the global scale (but see Rex et al., 2006, for a global analysis of abundance, biomass and body-size).

Consequently, in comparison to the terrestrial realm, biogeographical patterns for deep-sea benthic marine taxa and the reasons for such patterns are poorly understood (but see Harley et al., 2003), with even regional analyses of depth and latitudinal ranges scarce and limited to a few taxonomic groups (e.g. Macpherson \& Duarte, 1994; Macpherson, 2003; Cartes \& Carrassón, 2004). A general trend appears to be that eurybathyal species (wide vertical ranges) tend to have wide geographic ranges (Vinogradova, 1997), whereas stenobathyal species (narrow vertical ranges) tend to have much narrower geographic ranges, and particularly occur in the abyssal zone (> $3000 \mathrm{~m}$ depth; Vinogradova, 1997). Why these groups differ in terms of vertical distribution and horizontal range is not known. One reason may be the increasing large-scale fragmentation of benthic habitat with depth that occurs because physical barriers, such as mid-ocean ridges, isolate the seabed into separate basins. Life histories may also play a significant role, as some taxa with low dispersal capabilities appear to have smaller geographic ranges and a relatively high level of endemism on a regional scale (e.g. Brandt et al., 2007).

Although sampling has been limited, analyses of archived (e.g. Rex et al., 2005) and recently collected (e.g. Brandt et al., 2007) data, often gathered with great cost and effort, continue to provide insights into biogeographical patterns for deep-sea fauna. Given that this region is subject to increasing human pressures with, for example, fishing now taking place to depths of $2000 \mathrm{~m}$ (Sissenwine \& Mace, 2007), and climate change predicted to impact upon deep-sea communities such as coldwater coral reefs (Guinotte et al., 2006), it is becoming increasingly important to reach an understanding of the distribution of deep-sea species.

Because the spatial coverage of deep-sea records is very sparse, statistical modelling provides a useful tool with which to synthesize available data and give generality to our understanding of the ecology of such remote environments. Methods to model the distribution of species through relating occurrence data to environmental variables are increasingly being used in terrestrial biogeographical studies (e.g. see Araújo \& Guisan, 2006) and occasionally in the marine environment (Clark et al., 2006; Bryan \& Metaxas, 2007; Davies et al., 2008), although much less frequently. In this paper we use predictive modelling to explore the environmental variables that may limit the distribution of stony corals (Phylum Cnidaria; Class Anthozoa; Order Scleractinia) on seamounts, and to locate the areas that are most likely to provide suitable habitat.

Seamounts are widespread and prominent topographic features of the ocean floor. These undersea mountains are generally conical or conical with a truncated top, and of volcanic origin (Rogers, 1994; Wessel, 2007). Because mapping of the deep-sea floor is incomplete, the actual number of seamounts in the oceans is unknown, but there may be on the order of 100,000 with an elevation > $1000 \mathrm{~m}$ (Wessel, 2001). Seamounts provide an environment frequently characterized by enhanced currents (White et al., 2007) and, because of their predominantly volcanic origin, by the presence of rocky substrata (exceptions include the small minority of seamounts formed by tectonic uplift and flat-topped eroded seamounts on which extensive sedimentation has occurred) (Wessel, 2007).

These conditions favour the development of emergent epifaunal assemblages dominated by sessile suspension feeders, such as sponges and corals (Rogers, 1994; Koslow et al., 2001; Rogers et al., 2007; Samadi et al., 2007), and, as with other deep-sea communities, such assemblages often vary with depth (O'Hara, 2007; Rogers et al., 2007). The benthos of seamounts has been reported to be diverse, with a high proportion of endemic species (Parin et al., 1997; Richer de Forges et al., 2000), although this may not be the case for all taxa and regions (Samadi et al., 2006; Hall-Spencer et al., 2007; O'Hara, 2007). In some cases, large pelagic predators form aggregations to exploit the high availability of food resources sometimes associated with these features (Worm et al., 2003; Tynan et al., 2005; Holland \& Grubbs, 2007). Given the lack of consistency in patterns, and the low sampling effort in both seamount and non-seamount habitats for many regions, the ecological paradigms that have been associated with the fauna of seamounts have recently been questioned and further study has been called for (McClain, 2007).

Reefs formed by cold-water stony corals are common features on seamounts and the slopes of continental margins and islands (Roberts et al., 2006). These reefs may rival shallow-water tropical reefs in the diversity of some animal groups associated with the corals (Rogers, 1999). The number of species associated directly with cold-water corals can be high (e.g. Buhl-Mortensen \& Mortensen, 2005; Roberts et al., 2006), and a comparison between a reef habitat and an adjacent deepsea habitat revealed that reefs can support faunal assemblages of greater diversity (Henry \& Roberts, 2007). The structurally complex habitat formed by the corals is thought to promote such diversity (Freiwald et al., 2002), although the functional relationships between corals and their associated invertebrate taxa are not yet fully resolved (McClain, 2007; O'Hara et al., 2008; Rogers et al., 2008).

Cold-water corals are slow-growing (e.g. Andrews et al., 2005; Schröder-Ritzau et al., 2005; Roark et al., 2006) and vulnerable to a range of human threats, including bottom 

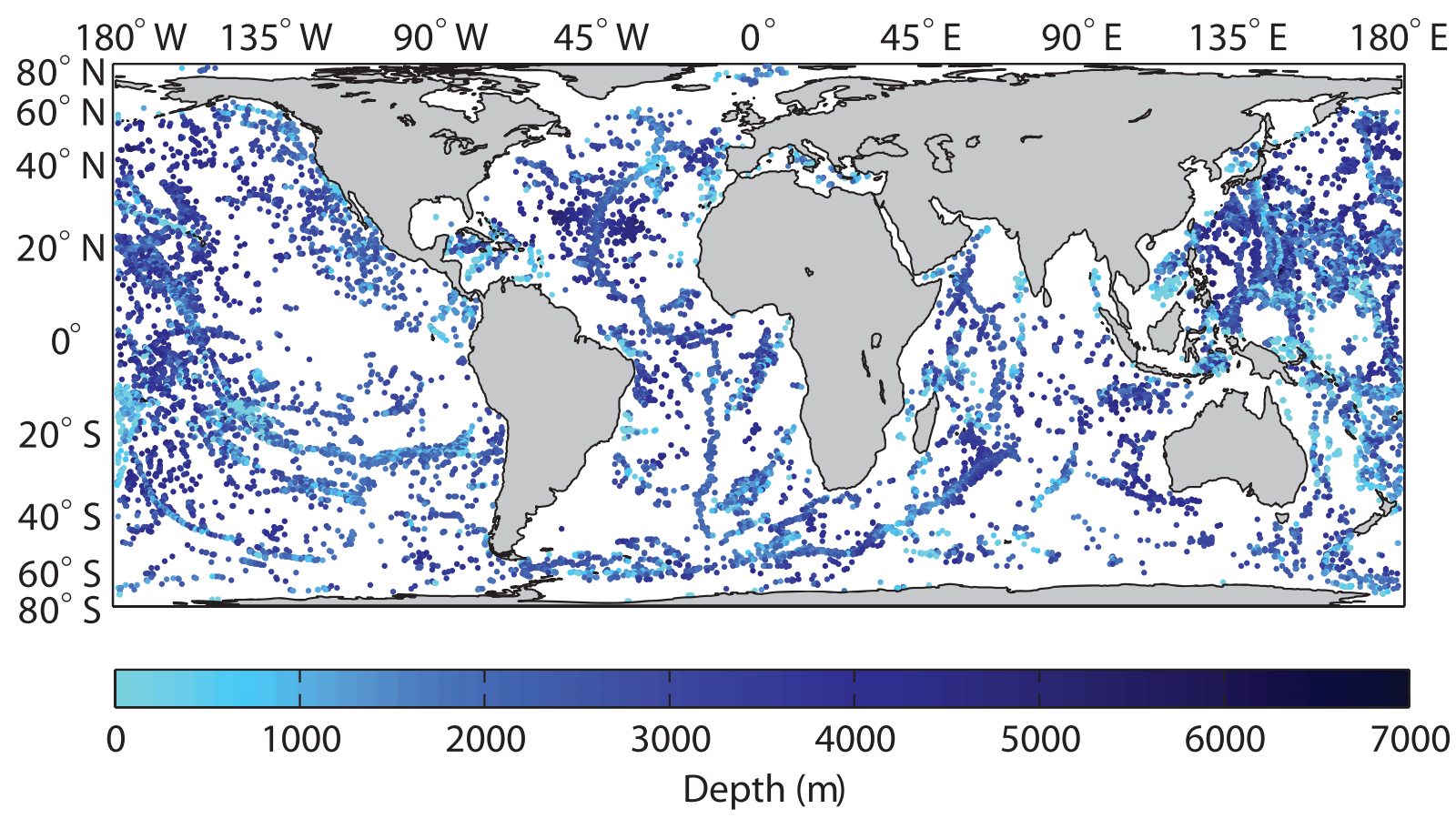

Figure 1 Potential large (> $1000 \mathrm{~m}$ height) seamount locations (c. 14,000) predicted from an analysis of global digital elevation data by Kitchingman \& Lai (2004), Behrmann projection. Colours indicate summit depth in metres.

trawling (e.g. Clark \& O’Driscoll, 2003; Freiwald et al., 2004; Clark \& Koslow, 2007), other forms of bottom-contact fishing (Stone, 2006; Edinger et al., 2007), hydrocarbon drilling (on continental margins; Rogers, 1999), seabed mining (Rogers et al., 2008) and ocean acidification (Guinotte et al., 2006). Especially on the high seas, but also in national waters, deepsea bottom fisheries target fish and shellfish stocks associated with seamounts (Clark et al., 2007; Watson et al., 2007), resulting in intense impacts on the benthic communities of these features, including coral ecosystems (Clark \& Koslow, 2007). Impacts on cold-water corals, both documented and predicted, are serious enough to warrant global efforts to conserve these unique and fragile ecosystems (e.g. UN General Assembly, 2006). However, any impact assessment and the development of conservation measures require data on the occurrence of corals on seamounts. Because these are available for only a very small fraction of the world's seamounts, our study was specifically designed to redress this critical information gap. We focus our efforts at a broad oceanic scale, whilst noting that the factors responsible for distributions may be markedly different at the scale of an individual seamount.

To predict the distribution of corals where presence data are lacking, we parameterized two habitat-suitability models with a recently compiled database of stony coral samples from seamounts (Rogers et al., 2007) and with global oceanic environmental data. Both modelling methods were developed to work with presence-only data (Hirzel et al., 2002; Phillips et al., 2006), that is, where true absence data are either unavailable or unreliable, as is the case for much of the deep sea. We then used the model output to construct maps of predicted habitat suitability for stony corals on seamounts.

\section{MATERIALS AND METHODS}

\section{Seamount data}

We used the most widely accepted definition of a 'large' seamount as having a vertical height $>1000 \mathrm{~m}$ above the surrounding sea-floor (Wessel, 2001). Seamount locations were obtained from the bathymetric analysis of Kitchingman \& Lai (2004), who identified 14,287 probable large seamounts globally. Fig. 1 shows the locations of seamounts predicted by this analysis, derived from a global bathymetry data set with a 2-min resolution. This analysis certainly does not contain every large seamount (see Wessel, 2001), as evidenced by the fact that the coral database we compiled has records from seamounts that were not detected. Thus we needed to make predictions for seamounts that exist but are not located by the method of Kitchingman \& Lai (2004). To resolve this, we modelled habitat suitability for the entire global ocean up to $2500 \mathrm{~m}$ in depth, but restricted coral presence data to seamounts only (i.e. we do not include coral records from other deep-sea habitats). In this way, we could assess global habitat suitability for those seamounts yet to be discovered, by predicting general habitat suitability for seamounts at each depth layer. We then mapped these depth layers to the summits of the c. 14,000 predicted seamounts (Kitchingman \& Lai, 2004).

\section{Coral data}

A database containing publicly accessible geo-referenced records of stony coral samples from seamounts has recently 

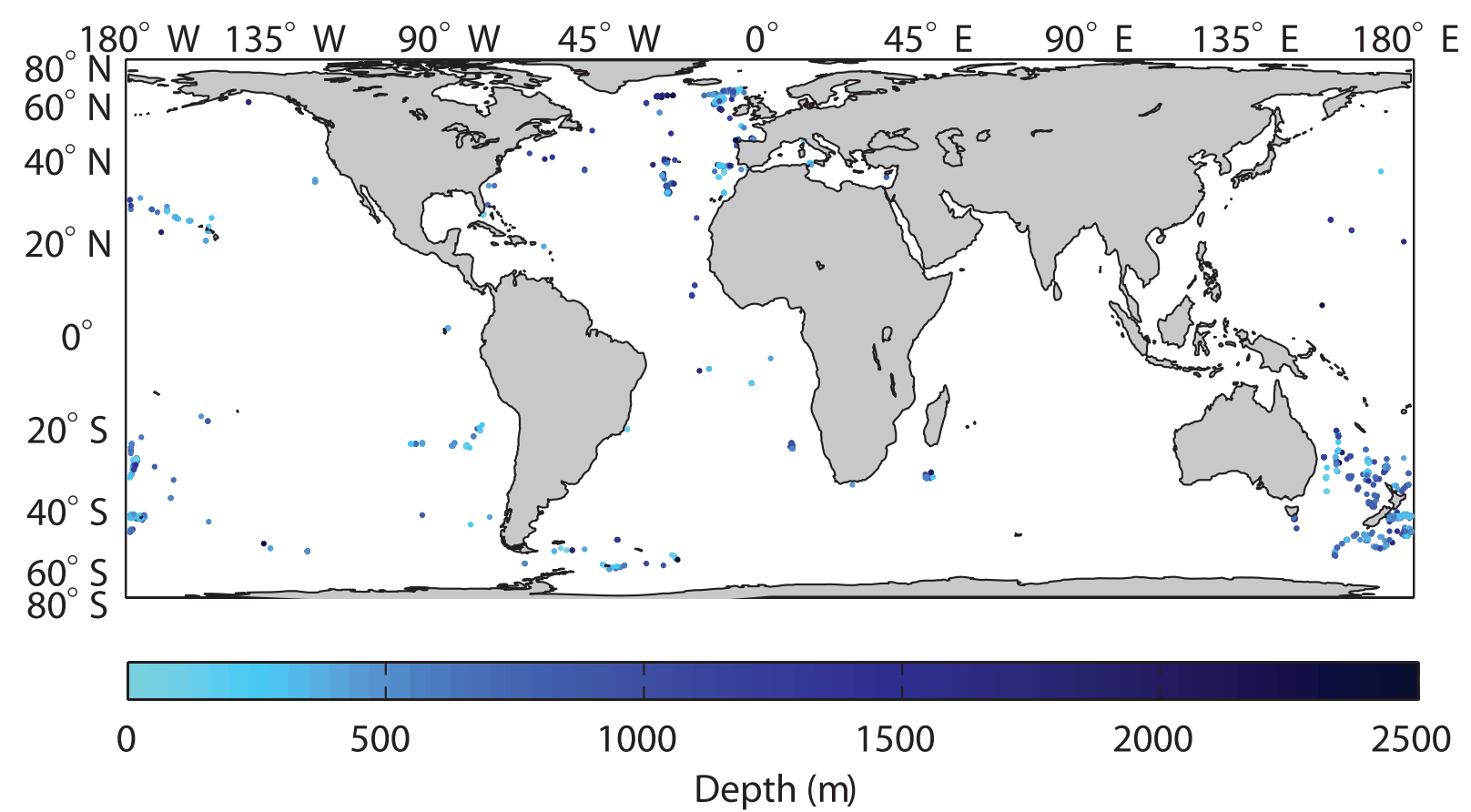

Figure 2 Locations of Scleractinia coral samples from seamounts, Behrmann projection. Colours indicate depth in metres.

been compiled (Rogers et al., 2007; database available through SeamountsOnline at http://seamounts.sdsc.edu/). Data sources included the primary scientific literature, online databases, museum databases, and records held by individual scientists. The geographic distribution of available coral records from seamounts is very uneven on a global scale (Fig. 2). Most samples come from the Southwest Pacific and the Northeast Atlantic, whereas only a few records are available for the Indian Ocean. In total, we compiled 1880 scleractinian records, of which 1651 contained latitude, longitude and depth information. Records of fossilized corals were excluded. For corals collected in trawls that recorded only the depth range over which samples were collected we used the midpoint of the reported range, and removed samples with a large depth range uncertainty (> $500 \mathrm{~m}, 11$ records). We binned the records of Scleractinia to the equal-area grid described below. The maximum depth of the analysis was $2500 \mathrm{~m}$, as there were too few records $(<10)$ at greater depth to parameterize the model beyond this point effectively; similarly, we used $50 \mathrm{~m}$ as a cutoff for the boundary between warm-water and cold-water corals (Cairns, 2007). Duplicate records were removed, providing a binary record of coral presence for each cell. A total of 433 grid cells contained stony coral presence records on seamounts.

\section{Environmental data}

Selecting the environmental variables likely to be important in determining the distribution of the taxa under study is an important component of the species distribution modelling process (Guisan \& Zimmermann, 2000). Our modelling procedure involved selecting environmental parameters for their potential importance in driving seamount coral distributions (determined through a literature review and expert opinion) at the grain of our study. We combined physical, biological and chemical oceanographic data from multiple sources (Table 1). All variables were remapped from a onedegree grid to the equal-area grid described below. The grid resolution was determined largely by the resolution of the environmental data; both World Ocean Atlas (WOA) and Global Ocean Data Analysis Project (GLODAP) data were available at a one-degree resolution. Where possible, data were selected from the 1990s for maximum congruence with the GLODAP environmental data. Physical data and primary productivity model output were all long-term annual means. The World Ocean Atlas 2005 data (http://www.nodc.noaa.gov/ OC5/WOA05/pr_woa05.html) used in our models were composite annual objectively analysed means. GLODAP gridded data (Key et al., 2004) were derived mostly from 1990s cruises. VGPM (Vertically Generalized Productivity Model) outputs (Behrenfeld \& Falkowski, 1997) were depth-integrated primary productivity values corrected for cloudiness, derived from chlorophyll data collected between 1977 and 1982. SODA (Simple Ocean Data Analysis) current velocities (Carton et al., 2000) were the grand mean of the annual means for the period 1990-99, using the 1.4.2 version of the model. The aragonite saturation state was calculated using GLODAP data and following the $\Delta\left[\mathrm{CO}_{3}^{2-}\right]_{\mathrm{A}}$ method of Orr et al. (2005), with equations following Zeebe \& Wolf-Gladrow (2001). Positive $\Delta\left[\mathrm{CO}_{3}^{2-}\right]_{\mathrm{A}}$ values indicate supersaturation; negative values, undersaturation. Depth was included as a parameter not because it is important per se, but because it may correlate with unmeasured variables. 
Table 1 Environmental parameters used to predict habitat suitability.

\begin{tabular}{|c|c|c|}
\hline Parameter & Source & Reference(s) \\
\hline Alkalinity (total), $\mu \mathrm{mol} \mathrm{kg}{ }^{-1}$ & GLODAP & Key et al. (2004) \\
\hline $\begin{array}{l}\Delta\left[\mathrm{CO}_{3}^{2-}\right]_{\mathrm{A}} \text { (aragonite } \\
\text { saturation state), } \mu \mathrm{mol} \mathrm{kg}{ }^{-1}\end{array}$ & $\begin{array}{l}\text { Derived } \\
\text { from } \\
\text { GLODAP } \\
\text { data }\end{array}$ & $\begin{array}{l}\text { Key et al. (2004); } \\
\text { Orr et al. (2005); } \\
\text { Zeebe \& Wolf- } \\
\text { Gladrow (2001) }\end{array}$ \\
\hline Depth, m & WOA & Locarnini et al. (2006) \\
\hline Dissolved oxygen, $\mathrm{mL} \mathrm{L}^{-1}$ & WOA & Garcia et al. (2006a) \\
\hline $\begin{array}{l}\text { Export primary productivity, } \\
\mathrm{mg} \mathrm{C} \mathrm{m}^{-2} \text { year }^{-1}\end{array}$ & VGPM & $\begin{array}{l}\text { Behrenfeld \& } \\
\text { Falkowski (1997); } \\
\text { Laws et al. (2000) }\end{array}$ \\
\hline Nitrate, $\mu \mathrm{mol} \mathrm{L}^{-1}$ & WOA & Garcia et al. (2006b) \\
\hline $\begin{array}{l}\text { Percentage oxygen } \\
\text { saturation, \% }\end{array}$ & WOA & Garcia et al. (2006a) \\
\hline Phosphate, $\mu \mathrm{mol} \mathrm{L}{ }^{-1}$ & WOA & Garcia et al. (2006b) \\
\hline $\begin{array}{l}\text { Primary productivity } \\
\text { (overlying water), } \\
\mathrm{mg} \mathrm{C} \mathrm{m}^{-2} \text { year }^{-1}\end{array}$ & VGPM & $\begin{array}{l}\text { Behrenfeld \& } \\
\text { Falkowski (1997) }\end{array}$ \\
\hline Salinity, pss & WOA & Antonov et al. (2006) \\
\hline Silicate, $\mu \mathrm{mol} \mathrm{L}^{-1}$ & WOA & Garcia et al. (2006b) \\
\hline $\begin{array}{l}\text { Total DIC (dissolved inorganic } \\
\text { carbon), } \mu \mathrm{mol} \mathrm{kg}{ }^{-1}\end{array}$ & GLODAP & Key et al. (2004) \\
\hline Temperature, ${ }^{\circ} \mathrm{C}$ & WOA & Locarnini et al. (2006) \\
\hline Regional current velocity, $\mathrm{cm} \mathrm{s}^{-1}$ & SODA & Carton et al. (2000) \\
\hline
\end{tabular}

GLODAP, Global Ocean Data Analysis Project; SODA, Simple Ocean Data Assimilation 1.4.2; VGPM, Vertically Generalized Productivity Model; WOA, World Ocean Atlas 2005.

\section{Equal-area global grid}

Global data are frequently provided in grids with cells equally spaced in latitude and longitude (e.g. the one-degree grid on which WOA data are provided). However, such 'geographic projections' are not equal-area, as the length of one degree of longitude (and, to a much lesser degree, latitude) varies considerably with latitude. For example, at $60^{\circ}$ of latitude (approximately the northern and southernmost boundaries of this study) one degree of longitude is half the length (in $\mathrm{km}$ ) that it would be at the equator. Thus a one-degree grid cell is approximately twice the size at the equator that it would be at $60^{\circ} \mathrm{N}$ or $60^{\circ} \mathrm{S}$. This has the potential to bias species distribution models that span a large latitudinal range; the greater the distance from the equator, the more important local-scale processes become.

In order to remove the effects of this potential bias from our study, we remapped all environmental data from one-degree grids onto an Equal-Area Scaleable Earth (EASE) grid (http:// nsidc.org/data/ease; see also Armstrong \& Brodzik, 1995). For the EASE grid in this study, we used a cylindrical equal-area projection with standard parallels at $\pm 30^{\circ}$ to minimize angular distortion over the region of analysis. The nominal grid-cell size was $c .130 \mathrm{~km}$, with the exact value chosen such that grid cells exactly spanned the equator, and that at the equator grid cells were slightly taller than one degree of latitude
- thus every grid cell contained at least one data point from the one-degree by one-degree grid on which much of the environmental data were binned. This resulted in a grid comprising 114 rows and 267 columns. The map origin was set to row 56.5 , column -0.5 ( $0^{\circ}$ latitude, $0^{\circ}$ longitude).

Vertically, data were linearly interpolated into depth bands spanning $250 \mathrm{~m}$ (i.e. the shallowest band ranged from 0 to $250 \mathrm{~m}$, and the deepest from 2250 to $2500 \mathrm{~m}$ ). Environmental layers needed to be in two-dimensional grids for input into our models; we converted three-dimensional grids by concatenating depth layers and using dummy variables for latitude and longitude.

Environmental data were remapped to the EASE grid by weighting one-degree grid-cell values by the area of the grid cells within each EASE cell. Coral data were mapped directly to the EASE grid. Models were also run on a one-degree grid to assess the effects of unequal grid-cell sizes on the robustness of the results.

\section{Models}

For some species, particularly those that are sessile or easily detectable, it is possible to census an environment to such an extent that the presence and the absence of individual species can be near-certain (e.g. trees in measured plots). A wide variety of statistical models are available for these types of data (Guisan \& Zimmermann, 2000). In many environments, however, it is not feasible to sample in a manner that provides reliable absence data. Although it is preferable to use both presence and absence data where available, because of the additional information that absence records contain (Brotons et al., 2004), presence-only statistical models have been developed for when absence data are unavailable (such as here).

We used Maxent (maximum entropy modelling; Phillips et al., 2006) and ENFA (environmental niche factor analysis; Hirzel et al., 2002), both of which were designed to handle presence-only data. ENFA is, as far as we know, the only habitat-suitability model previously applied to cold-water corals: regionally for gorgonians (Bryan \& Metaxas, 2007), and globally for the reef-forming scleractinian Lophelia pertusa (Davies et al., 2008). Maxent performs well in comparison with traditional methods such as generalized additive models (Elith et al., 2006), and ENFA is robust with respect to the quality and quantity of species distribution data (Hirzel et al., 2001). Both of these models are also fairly robust to correlations among environmental variables (Hirzel et al., 2002; Phillips et al., 2006), reducing some of the uncertainty arising from model selection. As with any generalized representation of real ecological systems, these models cannot capture the full complexity of underlying processes, and results should be viewed through this cautionary lens. In particular, no method exists for incorporating the effects of spatial autocorrelation within presence-only modelling techniques, unlike the case for presence/absence models (Dormann et al., 2007). In this instance, although we cannot rule out any effect of autocorrelation, given the resolution (grain) at which we are 
working it is reasonable to assume spatial independence between adjacent cells, and such effects are likely to be minimal.

\section{Maximum entropy modelling}

Maximum entropy modelling (Phillips et al., 2006) is a technique adopted from statistical mechanics. Given an unknown probability distribution $o$ (such as the distribution of a species) over a finite set X (such as the cells of a study area), we can approximate $o$ with a probability distribution $\hat{o}$. The information-theoretic entropy (Shannon, 1948) of this approximate distribution is defined as

$H(\hat{o})=-\sum_{x \in X} \hat{o}(x) \ln \hat{o}(x)$

In a general sense, the maximum entropy principle (Jaynes, 1957) suggests that the best approach to approximating an unknown probability distribution is to maximize entropy, subject to constraints (in this case, environmental data associated with species presences) representing incomplete information. A distribution with higher entropy is less 'constrained'; the maximum entropy principle therefore ensures that no unnecessary constraints are placed on $\hat{o}$. Algorithms guaranteed to converge to the maximum entropy distribution have been developed (Dudík et al., 2004).

We used Maxent software version 3.21 (http://www.cs. princeton.edu/ schapire/maxent) to fit the Maxent model, using default model parameters (a convergence threshold of $10^{-5}$, a maximum iteration value of 1000 and automatic regularization with a value of $10^{-4}$ ); these default settings have been shown to achieve good performance (Phillips \& Dudík, 2008). A jackknifing procedure was used to examine the importance of each variable, by comparing the model with that variable absent against that with it present. Habitat-suitability maps were constructed by calculating a raw probability value $p(x)$ for each grid cell $x$, such that the total of all cell probabilities summed to one. This value was then scaled logistically using the equation $c p(x) /(1+c p(x))$, where $c$ is the exponential of the entropy of the raw distribution, resulting in a relative habitat-suitability value ranging from zero to one. The logistic habitat-suitability values can be interpreted as an estimate of the probability of presence under a similar level of sampling effort as that used to obtain the known occurrence data (Phillips \& Dudík, 2008). All coral presence points were used to construct habitat-suitability maps.

\section{Environmental niche factor analysis}

Environmental niche factor analysis (ENFA) is a niche-based predictive habitat-suitability modelling technique for presenceonly data based on multivariate ordination (Hirzel et al., 2002). The factors produced by the model are uncorrelated and have biological significance. The first represents species marginality (the absolute difference between the global mean and the species mean in the multidimensional environmental space) and the remainder specialization (the ratio of the variance between the global distribution and the species distribution). A marginality value near to or $>1$ indicates that a species requires habitat substantially different from the background mean, and a specialization $>1$ indicates tolerance of a narrow range of environmental conditions (Hirzel et al., 2002); however, both of these values depend on the reference (background) environmental data used to construct the model. The factors are ordered by decreasing amounts of variance explained, except for the first factor, which explains all of the marginality and some portion of the specialization. In contrast to other ordination techniques, therefore, the first factor may explain less of the variance than subsequent factors.

We used the geometric mean algorithm to calculate a habitat-suitability index for each cell (Hirzel \& Arlettaz, 2003). The habitat-suitability maps were constructed using the isopleth method following Hirzel et al. (2002) and using all coral data. We used a broken-stick distribution to determine the number of factors (nine) with which to construct habitatsuitability maps. Habitat-suitability maps were indexed with a range of $0-100$, where higher values indicate more suitable habitat. ENFA assumes that data are multinormal (but see Hirzel et al., 2002) and that occurrence data span the environmental range of the taxonomic group in question. Prior to running the model, environmental data were normalized using the Box-Cox transformation (Sokal \& Rohlf, 1995). We used BIOMAPPER 4.0 (http://www.unil.ch/biomapper) and MATLAв 7.4 (http://www.mathworks.com) to run the ENFA model.

\section{Model evaluation}

Although many methods exist to evaluate the predictive capabilities of presence/absence models (Guisan \& Zimmermann, 2000), techniques to gauge the performance of presence-only models are still being developed (Boyce et al., 2002; Hirzel et al., 2006), because of the problems inherent in discriminating models predicting blanket presences from those that are more selective. Validation indices that have been developed for such situations are often dependent on arbitrarily selected thresholds. Recent developments, however, have shown considerable promise in resolving some of these difficulties (e.g. Hirzel et al., 2006; Phillips et al., 2006). We used a threshold-independent measure, the AUC (area under the curve), to assess our models (Zweig \& Campbell, 1993; Fielding \& Bell, 1997).

Although AUC was originally derived for presence/absence models, it can also be used for presence-only models. AUC is calculated by summing the area under a receiver operating characteristic (ROC) curve, which is a plot of sensitivity (fraction of true positives, i.e. the proportion of positive instances that are classified positive) against 1 - specificity (the false positive rate, i.e. the fraction of negative instances that are classified positive) for all possible thresholds. The value of an AUC index varies between 0 (performance worse than random) and 1 (perfect discrimination), with 0.5 being 
indistinguishable from random. Defined in this manner, ROC plots require presence/absence data. Plotting sensitivity against a random sample of background locations (i.e. without species presences) is equivalent to replacing absences with pseudoabsences, and is sufficient to define an ROC curve (Wiley et al., 2003; Phillips et al., 2006). Utilizing this method, however, means that, in contrast to an ROC curve created using presence/absence data for which the maximum obtainable AUC is 1 , the maximum achievable AUC is $1-a / 2$, where $a$ is the fraction of grid cells that the species' distribution covers. This is typically an unknown quantity, so it is not possible to determine how optimal an AUC value is when generated by this procedure. It is, however, possible to determine whether the AUC is statistically distinguishable from a random model (AUC value of 0.5), and to compare the prediction strength of multiple models using the same data. For the first procedure we used a Wilcoxon rank-sum test statistic, and for the second a nonparametric test based on the theory of generalized U-statistics (DeLong et al., 1988).

We used a cross-validation procedure to evaluate the performance of our models, by creating 10 random partitions of the occurrence localities, splitting the data in each partition between calibration (70\%) and evaluation (30\%) data sets. The same 10 random partitions were used for both models. AUC values were calculated for the evaluation data. Cross-validation procedures and statistical comparisons were carried out in MATLAB 7.4 (http://www.mathworks.com).

\section{RESULTS}

\section{Model evaluation}

Both models performed significantly better than random $(P<0.0001$; Wilcoxon rank-sum test $)$ for each and every partition of the data (AUC validation; Table 2). Although both

Table 2 AUC values for all model runs.

\begin{tabular}{lll}
\hline Partition & ENFA & Maxent \\
\hline 1 & 0.777 & 0.880 \\
2 & 0.782 & 0.875 \\
3 & 0.803 & 0.873 \\
4 & 0.803 & 0.877 \\
5 & 0.787 & 0.882 \\
6 & 0.792 & 0.890 \\
7 & 0.810 & 0.886 \\
8 & 0.814 & 0.876 \\
9 & 0.771 & 0.878 \\
10 & 0.784 & 0.898 \\
Mean (SD) & $0.792(0.015)$ & $0.882(0.008)$ \\
\hline
\end{tabular}

Models were calibrated using training data ( $70 \%$ of occurrence points, randomly selected), and AUC values were calculated from test data (30\% of occurrence points). All model runs fit significantly better than random $(P<0.0001)$. Maxent (maximum entropy modelling) AUC values were significantly higher than ENFA (environmental niche factor analysis) values for all partitions $(P<0.0001)$. models showed largely congruent geometric and bathymetric patterns of coral habitat, the Maxent model had a significantly better classification rate $[P<0.0001$; DeLong et al.'s (1988) nonparametric test] than the ENFA model for all 10 crossvalidation partitions. No partitions had significantly different AUC values when comparing EASE and one-degree grids, and environmental variables linked with regions of high/low habitat suitability were the same. Removing variables correlated at $>0.90$ and $>0.75$ had no significant impact on all cross-validations for Maxent and ENFA except one [Maxent cross-validation number 10 with variables correlated at $>0.90$ removed had a significantly lower AUC: $P=0.0054$; DeLong et al.'s (1988) nonparametric test]. Habitat-suitability maps and environmental variable responses were similar for models containing all variables and those with highly correlated variables removed; we focus on the models with all variables to allow for a fuller assessment of the factors potentially underlying distributions.

The maximum-entropy and ENFA models scale habitatsuitability values differently when constructing maps (see Materials and Methods), so direct comparison of absolute values is inappropriate. Instead we consider each habitatsuitability model separately.

\section{Maximum entropy modelling}

Predicted habitat suitability for the maximum entropy model is depicted in Fig. 3. Highly suitable habitat for cold-water stony corals on seamounts was predicted to occur in the North Atlantic at all depths down to $2500 \mathrm{~m}$, particularly in the eastern North Atlantic. In the Southern Hemisphere, highly suitable habitat was found at $<1500 \mathrm{~m}$ depth in parts of a circumglobal band located between $20^{\circ}$ and $50^{\circ} \mathrm{S}$. Some regions of the North Pacific (e.g. north-west of Hawaii and south-east of Japan) had suitable near-surface habitat, but only small areas below $750 \mathrm{~m}$ and almost none below $1000 \mathrm{~m}$. In the Indian Ocean almost all suitable habitat was predicted only south of the equator. Habitat suitability at depths below $1750 \mathrm{~m}$ (not shown) was similar to that displayed in Fig. 3(d). Jackknifing of variables and heuristic estimates (not shown) suggested that the aragonite saturation state $\left(\Delta\left[\mathrm{CO}_{3}^{2-}\right]_{\mathrm{A}}\right)$ and total DIC were the environmental variables most influential in determining habitat suitability; primary productivity and oxygen levels were also important. However, as a result of the high level of correlations among environmental variables it is difficult to determine the effects of individual factors in isolation.

\section{Environmental niche factor analysis}

The marginality value of the ENFA model was 1.430, indicating that cold-water stony corals had environmental requirements substantially offset from the background mean (Table 3). A specialization value of $>1$ (1.571) indicated that scleractinian corals on seamounts occupy relatively narrow environmental niches. Factors positively associated with high 


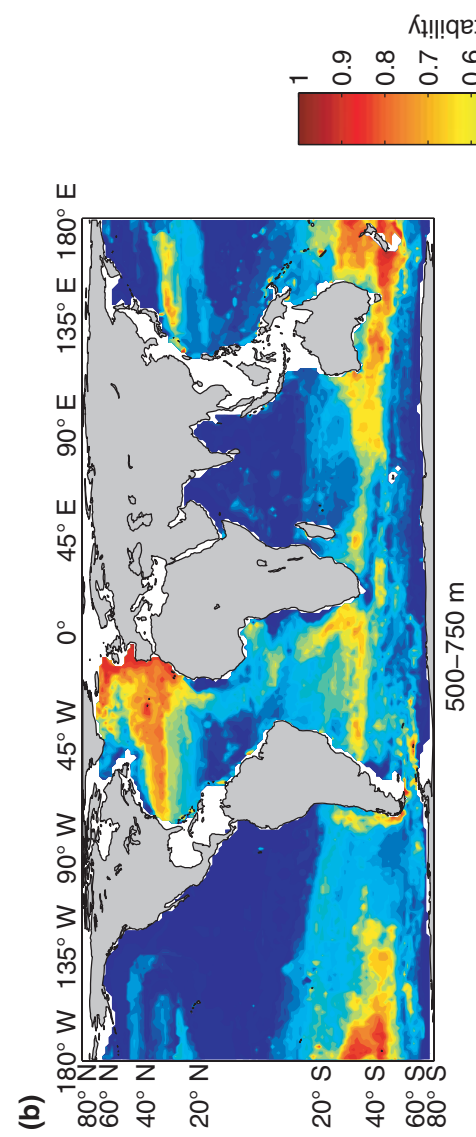

山
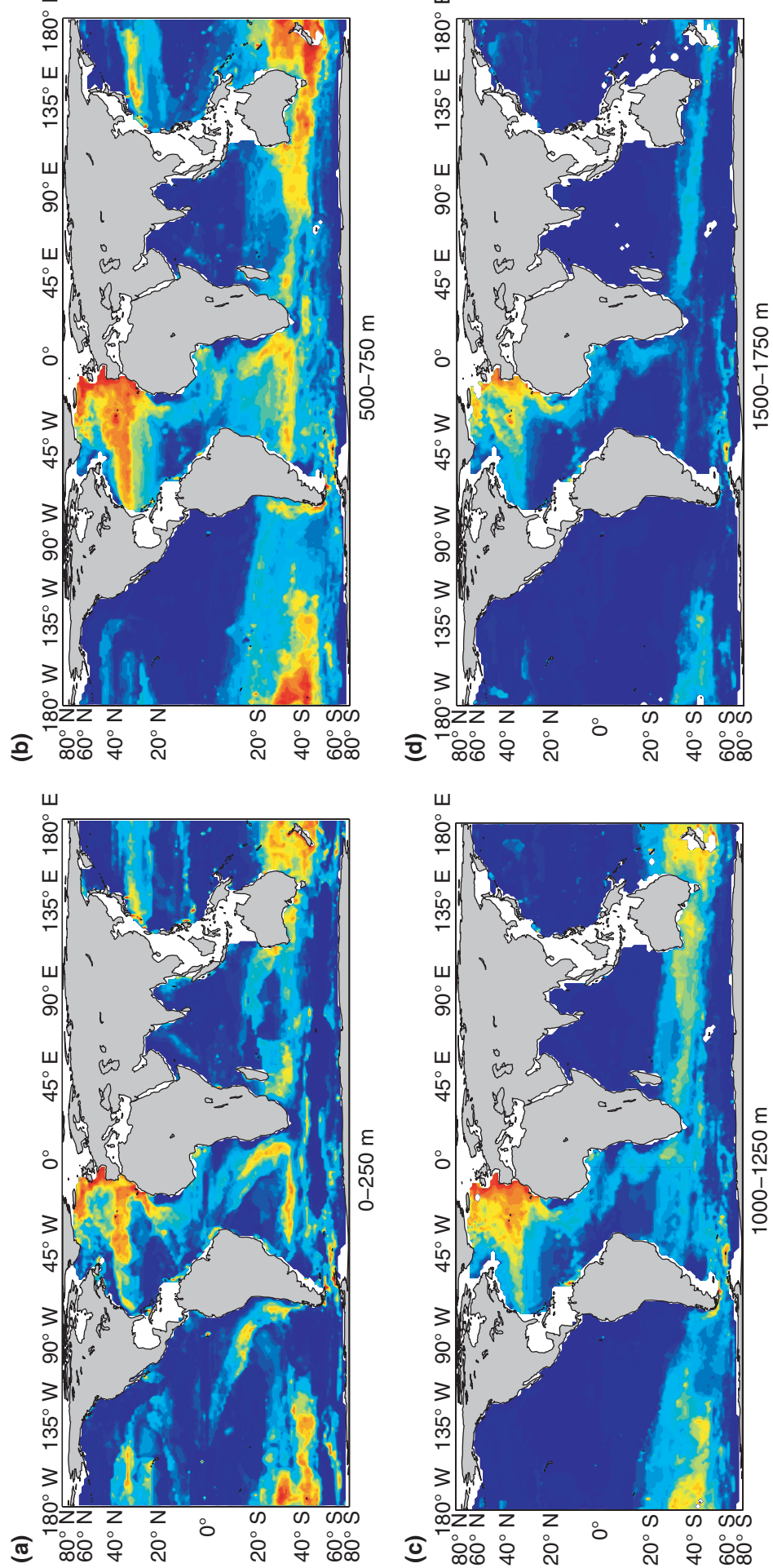

ш
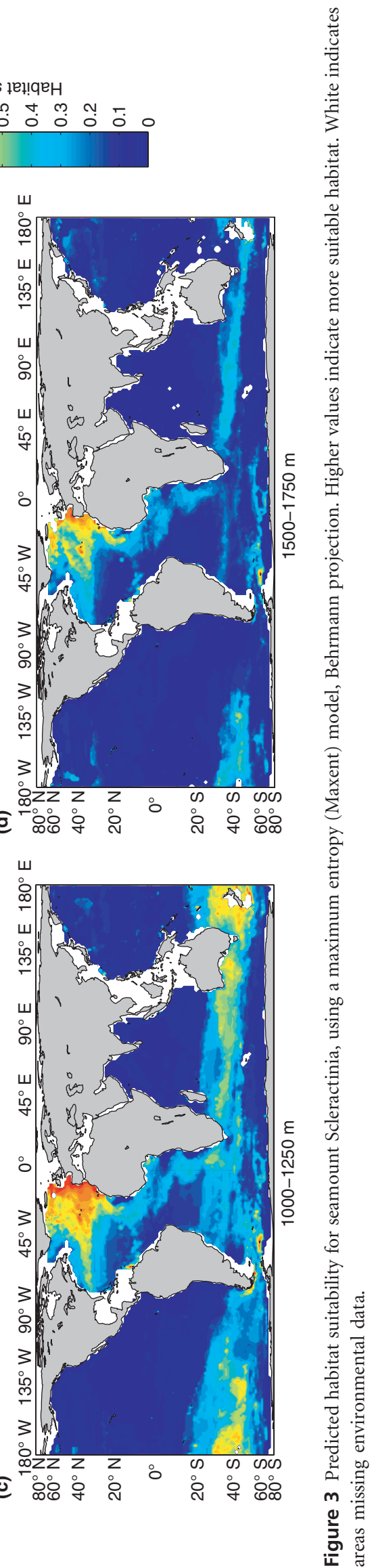
Table 3 Variance explained by the first nine ecological factors in the ENFA (environmental niche factor analysis) model.

\begin{tabular}{|c|c|c|c|c|c|c|c|c|c|}
\hline Factor & 1 (marginality) & 2 & 3 & 4 & 5 & 6 & 7 & 8 & 9 \\
\hline Alkalinity (total) & -0.257 & 0.003 & 0.117 & 0.026 & 0.048 & 0.021 & 0.294 & 0.394 & 0.476 \\
\hline$\Delta\left[\mathrm{CO}_{3}^{2-}\right]_{\mathrm{A}}$ (aragonite saturation state) & 0.313 & 0.109 & 0.229 & 0.455 & 0.143 & 0.016 & 0.001 & 0.110 & 0.102 \\
\hline Depth & -0.226 & 0.004 & 0.052 & 0.121 & 0.001 & 0.110 & 0.067 & 0.070 & 0.218 \\
\hline Dissolved oxygen & 0.251 & 0.397 & 0.538 & 0.517 & 0.622 & 0.637 & 0.399 & 0.159 & 0.086 \\
\hline Export productivity & 0.185 & 0.019 & 0.021 & 0.035 & 0.036 & 0.154 & 0.055 & 0.011 & 0.188 \\
\hline Nitrate & -0.320 & 0.425 & 0.109 & 0.022 & 0.098 & 0.044 & 0.425 & 0.361 & 0.328 \\
\hline Percentage oxygen saturation & 0.296 & 0.558 & 0.739 & 0.464 & 0.618 & 0.446 & 0.197 & 0.263 & 0.253 \\
\hline Phosphate & -0.322 & 0.570 & 0.146 & 0.092 & 0.104 & 0.062 & 0.170 & 0.068 & 0.051 \\
\hline Primary productivity & 0.297 & 0.011 & 0.035 & 0.028 & 0.107 & 0.098 & 0.109 & 0.018 & 0.049 \\
\hline Salinity & 0.152 & 0.061 & 0.000 & 0.105 & 0.077 & 0.002 & 0.214 & 0.048 & 0.194 \\
\hline Silicate & -0.349 & 0.032 & 0.093 & 0.141 & 0.192 & 0.352 & 0.142 & 0.452 & 0.585 \\
\hline Total DIC (dissolved inorganic carbon) & -0.317 & 0.046 & 0.197 & 0.460 & 0.346 & 0.010 & 0.397 & 0.622 & 0.103 \\
\hline Temperature & 0.249 & 0.077 & 0.118 & 0.206 & 0.113 & 0.468 & 0.511 & 0.069 & 0.302 \\
\hline Water velocity & -0.006 & 0.000 & 0.010 & 0.009 & 0.001 & 0.002 & 0.040 & 0.006 & 0.121 \\
\hline Explained specialization & 0.096 & 0.198 & 0.186 & 0.111 & 0.085 & 0.066 & 0.062 & 0.049 & 0.041 \\
\hline
\end{tabular}

Factor one explains the marginality; the remainder, the specialization. The cumulative explained specialization of the first nine factors is $89.5 \%$. Factor 1 explains $100 \%$ of the marginality.

habitat suitability included the aragonite saturation state $\left(\Delta\left[\mathrm{CO}_{3}^{2-}\right]_{\mathrm{A}}\right)$, dissolved oxygen concentration, and percentage oxygen saturation. Furthermore, low concentrations of phosphate, nitrate, silicate and dissolved inorganic carbon were all associated with high habitat suitability. Suitable coral habitat predicted using ENFA showed very similar patterns (Fig. 4) to those derived from the Maxent model (Fig. 3), although fewer fine-scale features were evident, and in general ENFA predicted larger areas containing suitable habitat. The biggest discrepancy between the models was the generally lower relative habitat suitability in the Northwest and tropical Atlantic in the Maxent model (Figs 3 \& 4).

\section{Habitat suitability for seamount summits}

The two models largely corresponded in their predictions of geographic and bathymetric patterns of cold-water stony coral habitat on likely seamount summits (Fig. 5). Because all depths in the North Atlantic were predicted to provide suitable habitat, many seamounts in this basin were highly suitable for corals irrespective of their summit depth (Fig. 5). In the circumglobal strip in the Southern Hemisphere, seamount summits above $1500 \mathrm{~m}$ depth were predicted to be suitable coral habitats, particularly in the Southwest Pacific around New Zealand, New Caledonia, Fiji and Tonga. ENFA predicted higher suitability of coral habitat for seamount summits in the tropical Atlantic; many summits identified in this region are below $1500 \mathrm{~m}$ depth (Fig. 1), where relative habitat suitability was predicted to be higher by the ENFA model (Figs $3 \mathrm{~d} \& 4 \mathrm{~d}$ ).

\section{DISCUSSION}

We used two presence-only modelling methods to construct habitat-suitability predictions for stony corals on seamounts. Both models showed similar spatial patterns of high and low suitability consistent with current knowledge. The Maxent approach had AUC values significantly higher than those of ENFA, indicating that it more accurately classified test locations as being suitable relative to background locations. Results were robust to correlations among variables and the model grid type (one-degree or equal-area). Mapping habitat suitability to the summits of $c .14,000$ predicted seamount locations showed a heterogeneous pattern of habitat suitability, with highly suitable summits in the North Atlantic and a midlatitude strip in the Southern Hemisphere. These patterns, and the underlying factors responsible, have potential implications for our understanding of the biogeography of stony corals in the deep sea and for developing worldwide conservation and management strategies for seamount ecosystems.

Disentangling the environmental factors responsible for constraining the distributions of stony corals on seamounts at the global scale is complex, and ultimately requires background knowledge of the ecosystem and of coral biology. Factors that were strongly correlated with high habitat suitability for these taxa may not in themselves be important, but may rather be correlated with another important variable. Furthermore, there was strong correlation between many of the environmental parameters used in the analyses, and although the models are robust to this, it further complicates the assignation of relative importance to each individual environmental variable. Nonetheless, the relative importance of each factor in the ENFA model (Table 3 ) and jackknife and heuristic results from the Maxent model (not shown) can be used to provide some guidance.

Of all the variables in the study, those of least importance were water velocity, export productivity, salinity and depth (Table 3). High water velocity or turbulent flow is known to be important in determining the distribution of cold-water corals at the local scale (metres to kilometres) on seamounts and in other geological settings (e.g. Genin et al., 1986; Frederiksen 

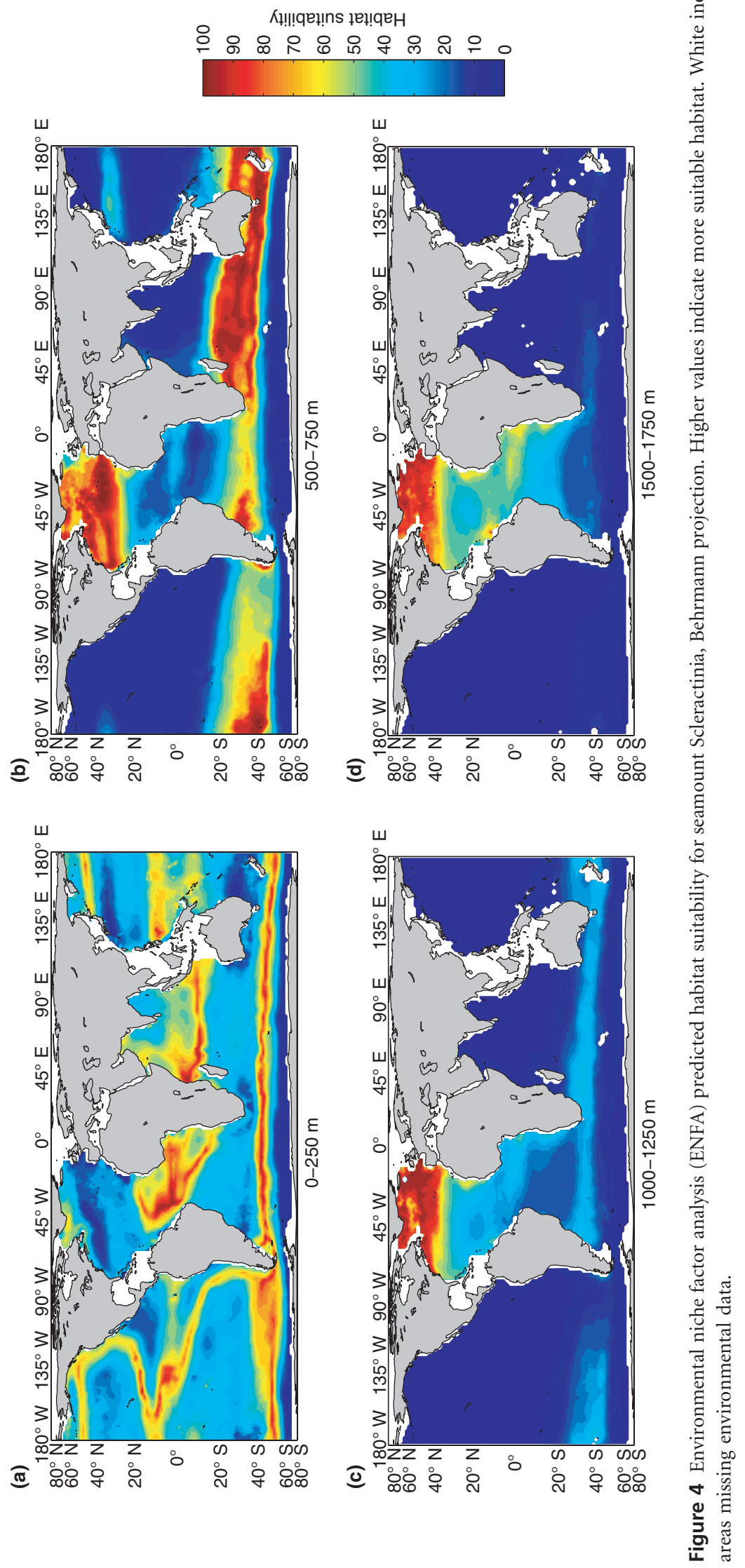

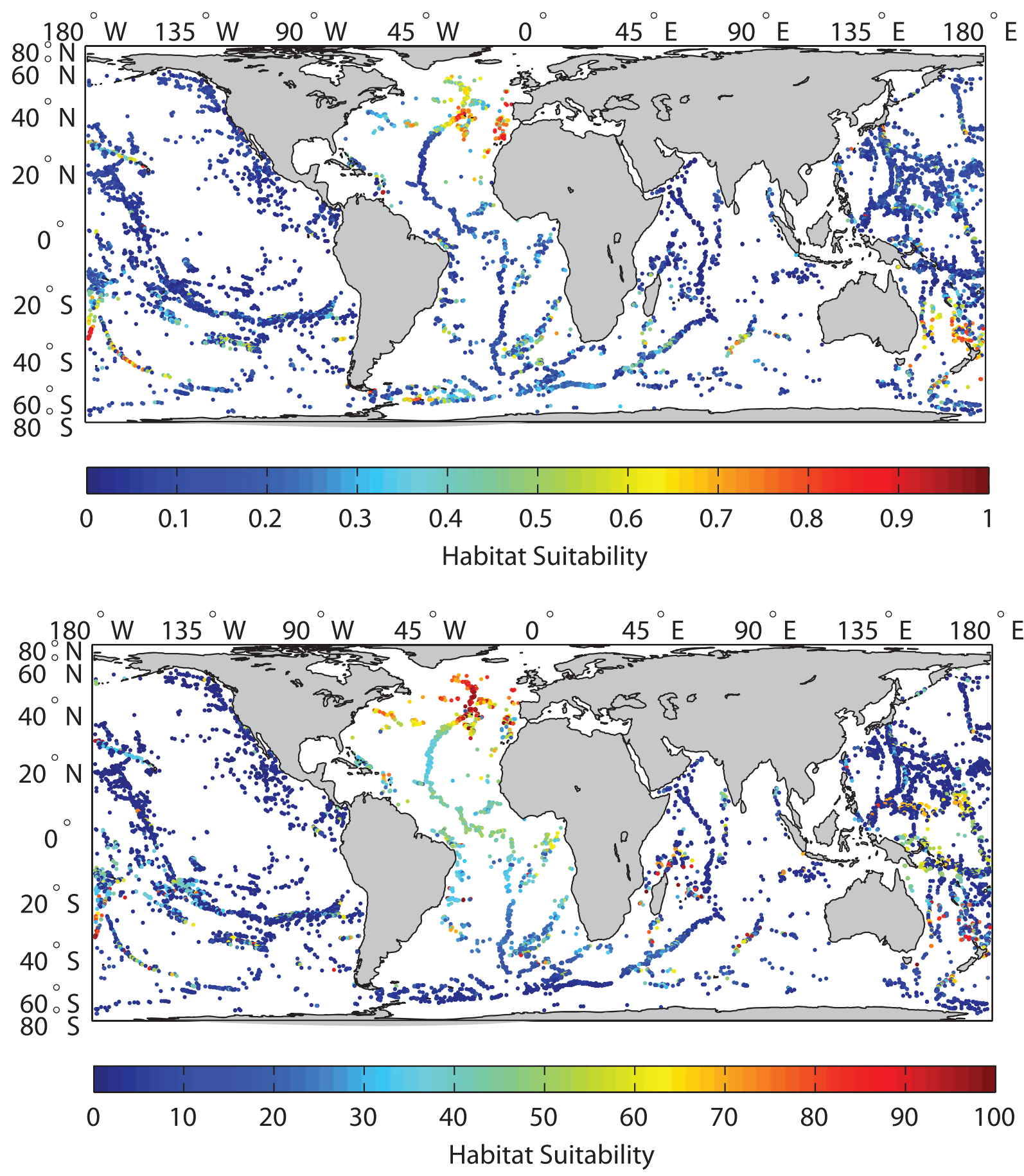

Figure 5 Predicted habitat suitability for Scleractinia on the summits of potential large seamounts, Behrmann projection. Top: results from the Maxent (maximum entropy modelling) model. Bottom: results from the ENFA (environmental niche factor analysis) model. Only seamounts with summit depths $<2500 \mathrm{~m}$ are included.

et al., 1992). Studies employing ENFA on deep-water octocorals and on the deep-water reef-forming scleractinian Lophelia pertusa have demonstrated that these corals favour areas of high current velocity or steep or irregular topography (Bryan \& Metaxas, 2007; Davies et al., 2008). High current flow can provide transport of nutrients and food to corals (e.g. Thiem et al., 2006) as well as preventing siltation of colonies and removing sediment from the seabed (Rogers, 1994). At the global scale, however, the averaging of velocity over the grid cells in the present study failed to capture the fine-resolution detail around each individual seamount, and hence the localized variation in flow.

Export productivity provided little information to the models, again probably because it failed to capture small-scale 
detail. However, this may also reflect the importance of advective processes in supplying food to seamount ecosystems, effectively de-coupling benthic communities from the regional level of primary production (Genin \& Dower, 2007; White et al., 2007).

In general, the relationships between cold-water coral distribution and salinity are poorly understood (Freiwald et al., 2004). Salinity partially determines the density of seawater and may be expected to influence stratification of the water column and small-scale oceanographic processes such as internal wave formation that may affect food supply to cold-water corals as well as other aspects of their ecology. A lack of evidence for the influence of salinity on habitat suitability for deep-sea stony corals may again reflect the inability of our analyses to capture the small scale at which such processes operate, but may also reflect the fact that other oceanographic processes may be important in driving food supply to cold-water corals on banks and seamounts (e.g. White et al., 2005; Duineveld et al., 2007).

Depth is unlike the other environmental parameters in that it is not a proximate factor potentially responsible for driving coral distributions per se, but rather is included in order to capture the potential effects of unmeasured variables. That it is of relative unimportance in model predictions suggests that there are no unmeasured factors highly correlated with depth that play a strong role in shaping stony coral distributions on seamounts, at least down to $2500 \mathrm{~m}$.

The environmental factors most important in determining habitat suitability appeared to be the aragonite saturation, dissolved oxygen and percentage oxygen saturation (Table 3). Aragonite saturation has been shown to closely regulate the calcification rates of zooxanthellate and azooxanthellate stony corals and other organisms (e.g. Leclercq et al., 2000; Kleypas et al., 2006), and has been speculated to constrain the distributions of cold-water stony corals (Guinotte et al., 2006). The models appeared to confirm this, with low suitability in the North Pacific, where the aragonite saturation horizon is shallow (c. 50-600 m) in comparison to the North Atlantic (c. 2500-3000 m) (Feely et al., 2004). For cold-water coral reefs, accumulation of the coral framework is a balance between coral growth and destruction of coral skeletons by bioeroding organisms such as sponges and polychaete worms (Rogers, 1999). Thus, conditions of low aragonite saturation are likely to be particularly unfavourable for cold-water coral reef formation as the balance between framework building processes and reef destruction is altered, especially as seawater can induce dissolution at low levels of saturation (Orr et al., 2005; Kleypas et al., 2006; Hoegh-Guldberg et al., 2007).

The strong influence of high oxygen concentrations on the occurrence of scleractinian corals was also found in an ENFA of the distribution of Lophelia pertusa, where the coral was found to occur in waters of $4.6-7.2 \mathrm{~mL} \mathrm{~L}^{-1}$ (Davies et al., 2008). This study was consistent with previous observations of the occurrence of $L$. pertusa in waters of oxygen concentrations of c. $4-5.5 \mathrm{~mL} \mathrm{~L}^{-1}$ (Freiwald, 2002). Ecophysiological studies on $L$. pertusa suggest that it cannot maintain aerobic metabolism at oxygen concentrations below $3 \mathrm{~mL} \mathrm{~L}^{-1}$ (Dodds et al., 2007). Hypoxia has also been demonstrated to decrease calcification rates in zooxanthellate corals in the dark (Al-Horani et al., 2007). This effect is negated in daylight by the production of oxygen during photosynthesis, a mechanism not available to deep-water corals (Al-Horani et al., 2007). Overall, it would appear that regions of the ocean where conditions of low oxygen exist are unsuitable as habitat for stony corals.

Low levels of nitrate, silicate and phosphate were also determined to be important for high relative habitat suitability, as found for L. pertusa (Davies et al., 2008). This result seems to confirm that nutrient concentrations, or factors correlated with nutrient concentrations, are important in determining cold-water stony coral distributions. Nutrient effects on coral growth have been extensively explored for warm-water corals, where nitrogen and phosphorus may increase photosynthesis in corals, but can inhibit calcification rates (Marubini \& Thake, 1999; Renegar \& Riegl, 2005; but see Langdon \& Atkinson, 2005). Furthermore, the effects of nutrient enrichment may be additive with the effects of low aragonite saturation, rendering the environment particularly unsuitable for the occurrence of scleractinian corals. Increased nutrients and temperature can both also increase the occurrence and severity of coral diseases in shallow-water stony corals (Bruno et al., 2003, 2007; Boyett et al., 2007). Studies of the effects of nutrients on calcification rates have not been carried out for cold-water corals, but these azooxanthellate corals do not photosynthesize, and hence we might speculate that only the negative effects of high nutrient concentrations may affect them.

The components of the seawater carbonate system (dissolved inorganic carbon, alkalinity, and $\left.\left[\Delta \mathrm{CO}_{3}^{2-}\right]_{\mathrm{A}}\right)$ are all highly correlated; high levels of $\left[\Delta \mathrm{CO}_{3}^{2-}\right]_{\mathrm{A}}$ are negatively correlated with dissolved inorganic carbon and alkalinity. Thus the availability of aragonite corresponds with low alkalinity and dissolved inorganic carbon.

Primary productivity was positively associated with habitat suitability, and interestingly appeared to be somewhat more influential in the Maxent model. This suggests that habitat suitability was nonlinearly related to primary productivity (Maxent marginal response curves, not shown), with a general trend towards high primary productivity being linked with high habitat suitability (Table 3, marginality).

All of the above-mentioned environmental variables are strongly correlated $(|\rho|>0.5$ with at least one other variable). For example, oxygen saturation of seawater is directly related to temperature and both show marked patterns of variation with depth. Temperature generally decreases with increasing depth, and oxygen concentration drops to a minimum below the surface prior to increasing again with increasing depth. This leaves as yet unresolved the question of which factors are the most important in determining the suitability of seamount habitat for stony corals. Experimental and observational studies on calcification rates in cold-water corals and responses to physical and biogeochemical environmental parameters are required to resolve this question (see Kleypas et al., 2006). 
The patterns predicted by the models (Figs 3-5) are largely consistent with current biogeographical knowledge for this taxon (Guinotte et al., 2006; Rogers et al., 2007). The Atlantic has a relatively deep aragonite saturation horizon and high oxygen availability, thus providing suitable conditions for corals to grow (e.g. Rogers, 1999; Hall-Spencer et al., 2007). The circumglobal strip of suitable habitat in the Southern Hemisphere corresponds very well with a relatively deep aragonite saturation depth (Feely et al., 2004) and a high level of dissolved oxygen in comparison to surrounding regions (Garcia et al., 2006a). In contrast, the equatorial Pacific has a much shallower aragonite saturation depth and lower levels of dissolved oxygen. This is likely to be responsible for the low habitat suitability at every depth except for some near-surface patches in the ENFA model. The North Pacific Ocean also has a much shallower aragonite saturation horizon (Feely et al., 2004), which could be responsible for the low predicted habitat suitability at depth. Samples from North Pacific seamounts do appear to indicate reduced abundance of scleractinians relative to many other regions (Baco, 2007). The northern Indian Ocean is a well-known extreme oxygen minimum zone (e.g. Helly \& Levin, 2004; Garcia et al., 2006a), and both models predict low habitat suitability at all depths for this region. Although there are few presence data in the model from the southern Indian Ocean, this entire region is predicted to be highly suitable habitat. Thus, at a global level, the model predicts high habitat suitability for both well-sampled (e.g. Northeast Atlantic) and less well-sampled (e.g. South Indian Ocean) regions. Therefore, our models largely reflect the known biogeography of this taxon, but in addition provide predictions of highly suitable regions that are not yet well sampled. It will prove interesting to see whether seamounts in these regions do indeed have cold-water scleractinians in any abundance.

The geographical distribution also reflects previously proposed historical and ecological factors responsible for largescale coral patterns in the deep sea. For example, the abundance of cold-water corals in the Southwest Pacific is thought to be the result of shallow to deepwater dispersal of fauna from the centre of coral speciation in the Indo-West Pacific (a region that had originated by the early Miocene), and of the number and concentration of seamounts that could facilitate effective dispersal (Cairns, 2007). Thus, the results of the predictive modelling of suitable habitat for stony corals on the summits of seamounts largely confirms rather than significantly questions the current views on dispersal and colonization by corals in the deep sea, and what little is known about seamount biogeography in general (Stocks \& Hart, 2007).

The maps of habitat suitability on seamount summits (Fig. 5) provide useful guidance as to areas containing seamounts with highly suitable habitat. However, we are limited by the constraints of the data. First, numerous seamounts are undoubtedly not detected through this approach, some of which are likely to be located in regions of high habitat suitability. For example, the Kitchingman \& Lai (2004) analysis does not detect any seamounts to the northwest of Britain and Ireland, but both the ENFA and Maxent models suggest that this is a region of high suitability. Second, habitat suitability on seamount summits is likely to differ from that on seamount flanks, especially for those regions where habitat suitability varies substantially by depth (for example, the general decrease in habitat suitability with depth in the circumglobal southern latitude strip; Figs $3 \& 4$ ). Finally, the modelling of habitat suitability from environmental variables tells us nothing about the role of biological interactions in determining the distribution of stony corals on seamounts. We point out, however, that past approaches to explaining deepsea diversity and species distributions that have concentrated on ecologically based explanations (for example niche specialization, Sanders, 1969; intermediate disturbance hypotheses, Dayton \& Hessler, 1972) have largely failed to provide a satisfactory explanation of species diversity and patterns of species occurrence (Gage, 2004). Such interactions may actually have a limited impact on the diversity that occurs at a local scale (see Cornell \& Lawton, 1992, for terrestrial communities). Instead, diversity is likely to be set at the regional level by environmental parameters and evolutionary history. Food resources are an overwhelming limiting factor in deep-sea communities (Rex et al., 2006), suggesting that the competition for food and space that occurs in many shallow water marine habitats is unlikely to have a strong impact on species distributions in the deep sea. Therefore, we believe that the conclusions are probably not significantly affected by interspecies interactions, although they may be influenced by biogeography (Cairns, 2007).

The Maxent model outperformed the ENFA model for every cross-validation partition (Table 2). Maxent can fit more complex functions of environmental variables, including thresholds, quadratic functions and products. ENFA, in contrast, is only able to fit linear dependencies of the species niche (Hirzel et al., 2002), unless transformations or nonlinear combinations of variables are also incorporated as layers. However, this means that ENFA results (Table 3) regarding the importance of each variable are more straightforward to interpret than the heuristic and jackknifing estimates output with Maxent. Given our results, we recommend the testing of multiple modelling approaches on deep-sea presence-only data, along with threshold-independent metrics of validation, as there may be substantial differences in performance. Nonetheless, both models fit with AUC scores of $>0.75$ for all crossvalidation partitions, which indicates good discrimination ability appropriate for many uses (Pearce \& Ferrier, 2000).

\section{CONCLUSIONS}

Stony corals are slow-growing, long-lived and vulnerable organisms, particularly on seamounts, which are often the target of exploitation because of the high concentrations of fish present (Rogers, 1994). The maps derived from our statistical models suggest that global habitat for scleractinians on seamounts is highly heterogeneous, being concentrated in the North Atlantic and in a circumglobal strip between $20^{\circ}$ and $50^{\circ} \mathrm{S}$. This pattern generally reflects what is known about the 
biogeography of stony corals in the deep sea, although samples have not been taken from some regions of the ocean predicted to be suitable habitat for this taxon (e.g. the South Indian Ocean). The modelling that we have carried out presents a testable hypothesis as to the distribution of stony corals on seamounts. Further sampling could lend weight to or falsify this hypothesis.

Our analysis also provides a comparison of two presenceonly habitat-suitability modelling methods: ENFA and Maxent. In this instance, Maxent consistently provided a better classification of coral presence data using a cross-validation procedure. This may be because Maxent is able to fit more complex functions of environmental variables. We propose that threshold-independent comparisons be conducted whenever predictive modelling of habitat suitability for deep-sea organisms is conducted, in order to properly assess the performance and idiosyncrasies of individual models, and consequential effects on predictions.

Higher-resolution environmental data or additional coral samples would allow for further refinement of these models. Knowledge of likely differences in coral habitat between seamount summits and seamount flanks, and for different types of seamounts would also greatly increase our understanding. This understanding could come through fine-scale predictive modelling of habitat suitability on individual seamounts, were such data available, and would provide enormous insight into the small-scale factors that are important for these organisms. Local-scale models could also reveal further regional differences, and species-specific analyses may identify varied requirements within the Scleractinia.

Human impacts on cold-water corals can be substantial (Davies et al., 2007). Such effects may grow in the future as a result of climate change and increased exploitation pressure. The likely shallowing of the aragonite saturation horizon (Orr et al., 2005) may well have a negative effect on habitat suitability for cold-water stony corals on seamounts (Guinotte et al., 2006). Furthermore, exploitation pressure must be considered in concert with coral habitat when addressing issues of conservation and management. Our analysis suggests that efforts to protect these fragile organisms on seamounts must take the spatial heterogeneity of suitable habitat into account. This suitable habitat may be mostly limited to the North Atlantic and a circumglobal strip in the Southern Hemisphere. The potential importance of these corals for their associated assemblages suggests that increasing our understanding of their distribution is important in helping to protect seamount biodiversity. Using predictive models to maximize understanding gleaned from sampling efforts is one way in which to do this.

\section{ACKNOWLEDGEMENTS}

We would like to thank R. A. Myers, B. Worm, J. McPherson, W. Blanchard and A. Dickson for guidance and advice. We are grateful to the anonymous referees for their constructive criticisms and suggestions. This paper is a joint product of the CenSeam and FMAP programs of the Census of Marine Life, as supported by the Sloan Foundation. The ideas for this paper were conceived at the CenSeam Data Analysis Working Group workshop in Wellington, New Zealand, sponsored by the Netherlands Department of Nature, Ministry of Agriculture, Nature and Food Quality. An earlier iteration of one habitat-suitability model (ENFA) was included in UNEP Regional Seas Report and Studies No. 183. SeamountsOnline has received support from NSF OCE, NSF BDI and the Sloan Foundation.

\section{REFERENCES}

Al-Horani, F.A., Tambutté, É. \& Allemand, D. (2007) Dark calcification and the daily rhythm of calcification in the scleractinian coral, Galaxea fascicularis. Coral Reefs, 26, 531538.

Andrews, A.H., Cailliet, G.M., Kerr, L.A., Coale, K.H., Lundstrom, C. \& DeVogelaere, A.P. (2005) Investigations of age and growth for three deep-sea corals from the Davidson Seamount off central California. Cold-water corals and ecosystems (ed. by A. Freiwald and J.M. Roberts), pp. 10211038. Springer-Verlag, Berlin.

Antonov, R.A., Locarnini, R.A., Boyer, T.P., Mishonov, A.V. \& Garcia, H.E. (2006) World Ocean Atlas 2005, Vol. 2: Salinity (ed. by S. Levitus). US Government Printing Office, Washington, DC.

Araújo, M.B. \& Guisan, A. (2006) Five (or so) challenges for species distribution modelling. Journal of Biogeography, 33, 1677-1688.

Armstrong, R.L. \& Brodzik, M.J. (1995) An earth-gridded SSM/I data set for cryospheric studies and global change monitoring. Advances in Space Research, 16, 155-163.

Baco, A.R. (2007) Exploration for deep-sea corals on North Pacific seamounts and islands. Oceanography, 20, 108-117.

Behrenfeld, M.J. \& Falkowski, P.G. (1997) Photosynthetic rates derived from satellite-based chlorophyll concentration. Limnology and Oceanography, 42, 1-20.

Boyce, M.S., Vernier, P.R., Nielsen, S.E. \& Schmiegelow, F.K.A. (2002) Evaluating resource selection functions. Ecological Modelling, 157, 281-300.

Boyett, H.V., Bourne, D.G. \& Willis, B.L. (2007) Elevated temperature and light enhance progression and spread of black band disease on staghorn corals of the Great Barrier Reef. Marine Biology, 151, 1711-1720.

Brandt, A., Gooday, A.J., Brandão, S.N., Brix, S., Brökeland, W., Cedhagen, T., Choudhury, M., Cornelius, N., Danis, B., De Mesel, I., Diaz, R.J., Gillan, D.C., Ebbe, B., Howe, J.A., Janussen, D., Kaiser, S., Linse, K., Malyutina, M., Pawlowski, J., Raupach, M. \& Vanreusel, A. (2007) First insights into the biodiversity and biogeography of the Southern Ocean deep sea. Nature, 447, 307-311.

Brotons, L., Thuiller, W., Araújo, M.B. \& Hirzel, A.H. (2004) Presence-absence versus presence-only modelling methods for predicting bird habitat suitability. Ecography, 27, 437448. 
Bruno, J.F., Petes, L.E., Harvell, C.D. \& Hettinger, A. (2003) Nutrient enrichment can increase the severity of coral diseases. Ecology Letters, 6, 1056-1061.

Bruno, J.F., Selig, E.R., Casey, K.S., Page, C.A., Willis, B.L., Harvell, C.D., Sweatman, H. \& Melendy, A.M. (2007) Thermal stress and coral cover as drivers of coral disease outbreaks. PLoS Biology, 5, 1220-1227.

Bryan, T.L. \& Metaxas, A. (2007) Predicting suitable habitat for deep-water gorgonian corals on the Atlantic and Pacific continental margins of North America. Marine Ecology Progress Series, 330, 113-126.

Buhl-Mortensen, L. \& Mortensen, P.B. (2005) Distribution and diversity of species associated with deep-sea gorgonian corals off Atlantic Canada. Cold-water corals and ecosystems (ed. by A. Freiwald and J.M. Roberts), pp. 849-879. Springer-Verlag, Berlin.

Cairns, S.D. (2007) Deep-water corals: an overview with special reference to diversity and distribution of deepwater scleractinian corals. Bulletin of Marine Science, 81, 311-322.

Cartes, J.E. \& Carrassón, M. (2004) Influence of trophic variables on the depth-range distributions and zonation rates of deep-sea megafauna: the case of the Western Mediterranean assemblages. Deep-Sea Research I, 51, 263-279.

Carton, J.A., Chepurin, G., Cao, X. \& Giese, B. (2000) A simple ocean data assimilation analysis of the global upper ocean 1950-95. Part I: methodology. Journal of Physical Oceanography, 30, 294-309.

Clark, M.R. \& Koslow, J.A. (2007) Impacts of fisheries on seamounts. Seamounts: ecology, fisheries and conservation (ed. by T.J. Pitcher, T. Morato, P.J.B. Hart, M.R. Clark, N. Haggan and R.S. Santos), pp. 413-441. Blackwell Publishing, Oxford.

Clark, M. \& O’Driscoll, R. (2003) Deepwater fisheries and aspects of their impact on seamount habitat in New Zealand. Journal of Northwest Atlantic Fishery Science, 31, 441-458.

Clark, M.R., Tittensor, D., Rogers, A.D., Brewin, P., Schlacher, T., Rowden, A., Stocks, K. \& Consalvey, M. (2006) Seamounts, deep-sea corals and fisheries: vulnerability of deep-sea corals to fishing on seamounts beyond areas of national jurisdiction. UNEP-WCMC, Cambridge.

Clark, M.R., Vinnichenko, V.I., Gordon, J.D.M., Beck-Bulat, G.Z., Kukharev, N.N. \& Kakora, A.F. (2007) Large-scale distant-water trawl fisheries on seamounts. Seamounts: ecology, fisheries and conservation (ed. by T.J. Pitcher, T. Morato, P.J.B. Hart, M.R. Clark, N. Haggan and R.S. Santos), pp. 361-399. Blackwell Publishing, Oxford.

Cornell, H.V. \& Lawton, J.H. (1992) Species interactions, local and regional processes, and limits to the richness of ecological communities: a theoretical perspective. Journal of Animal Ecology, 61, 1-12.

Davies, A.J., Roberts, J.M. \& Hall-Spencer, J. (2007) Preserving deep-sea natural heritage: emerging issues in offshore conservation and management. Biological Conservation, 138, 299-312.
Davies, A.J., Wisshak, M., Orr, J.C. \& Roberts, J.M. (2008) Predicting suitable habitat for the cold-water coral Lophelia pertusa (Scleractinia). Deep-Sea Research I, 55, 10481062.

Dayton, P.K. \& Hessler, R.R. (1972) Role of biological disturbance in maintaining diversity in the deep sea. Deep-Sea Research, 19, 199-208.

DeLong, E.R., DeLong, D.M. \& Clarke-Pearson, D.L. (1988) Comparing the areas under two or more correlated receiver operating characteristic curves: a nonparametric approach. Biometrics, 44, 837-845.

Dodds, L.A., Roberts, J.M., Taylor, A.C. \& Marubini, F. (2007) Metabolic tolerance of the cold-water coral Lophelia pertusa (Scleractinia) to temperature and dissolved oxygen change. Journal of Experimental Marine Biology and Ecology, 349, 205-214.

Dormann, C.F., McPherson, J.M., Araújo, M.B., Bivand, R., Bolliger, J., Gudrun, C., Davies, R.G., Hirzel, A., Jetz, W., Kissling, D., Kühn, I., Ohlemüller, R., Peres-Neto, P.R., Reineking, B., Schröder, B., Schurr, F.M. \& Wilson, R. (2007) Methods to account for spatial autocorrelation in the analysis of species distributional data: a review. Ecography, 30, 609-628.

Dudík, M., Phillips, S.J. \& Schapire, R.E. (2004) Performance guarantees for regularized maximum entropy density estimation. Proceedings of the 17th Annual Conference on Computational Learning Theory (ed. by J. Shawe-Taylor and Y. Singer), pp. 472-486. Springer-Verlag, Berlin.

Duineveld, G.C.A., Lavaleye, M.S.S., Bergman, M.J.N., de Stigter, H. \& Mienis, F. (2007) Trophic structure of a coldwater coral mound community (Rockall Bank, NE Atlantic) in relation to the near-bottom particle supply and current regime. Bulletin of Marine Science, 81, 449-467.

Edinger, E., Baker, K., Devillers, R. \& Wareham, V. (2007) Coldwater corals off Newfoundland and Labrador: distribution and fisheries impacts. WWF-Canada, Toronto.

Elith, J., Graham, C.H., Anderson, R.P., Dudík, M., Ferrier, S., Guisan, A., Hijmans, R.J., Huettmann, F., Leathwick, J.R., Lehmann, A., Li, J., Lohmann, L.G., Loiselle, B.A., Manion, G., Moritz, C., Nakamura, M., Nakazawa, Y., Overton, J.M., Peterson, A.T., Phillips, S.J., Richardson, K., ScachettiPereira, R., Schapire, R.E., Soberón, J., Williams, S., Wisz, M.S. \& Zimmermann, N.E. (2006) Novel methods improve prediction of species' distributions from occurrence data. Ecography, 29, 129-151.

Feely, R.A., Sabine, C.L., Lee, K., Berelson, W., Kleypas, J., Fabry, V.J. \& Millero, F.J. (2004) Impact of anthropogenic $\mathrm{CO}_{2}$ on the $\mathrm{CaCO}_{3}$ system in the oceans. Science, 305, 362366.

Fielding, A.H. \& Bell, J.F. (1997) A review of methods for the assessment of prediction errors in conservation presence/ absence models. Environmental Conservation, 24, 38-49.

Frederiksen, R., Jensen, A. \& Westerberg, H. (1992) The distribution of the scleractinian coral Lophelia pertusa around the Faroe Islands and the relation to internal tidal mixing. Sarsia, 77, 157-171. 
Freiwald, A. (2002) Reef-forming cold-water corals. Ocean margin systems (ed. by G. Wefer, D. Billett, D. Hebbeln, B.B. Jørgensen, M. Schlüter and T. van Weering), pp. 365-385. Springer-Verlag, Berlin.

Freiwald, A., Hühnerbach, V., Lindberg, B., Wilson, J.B. \& Campbell, J. (2002) The Sula Reef Complex, Norwegian Shelf. Facies, 47, 179-200.

Freiwald, A., Fossă, J.H., Grehan, A., Koslow, T. \& Roberts, J.M. (2004) Cold-water coral reefs. UNEP-WCMC, Cambridge.

Gage, J.D. (2004) Diversity in deep-sea benthic macrofauna: the importance of local ecology, the larger scale, history and the Antarctic. Deep-Sea Research II, 51, 1689-1708.

Garcia, H.E., Locarnini, R.A., Boyer, T.P. \& Antonov, J.I. (2006a) World Ocean Atlas 2005, Vol. 3: Dissolved oxygen, apparent oxygen utilisation, and oxygen saturation (ed. by S. Levitus). US Government Printing Office, Washington, DC.

Garcia, H.E., Locarnini, R.A., Boyer, T.P. \& Antonov, J.I. (2006b) World Ocean Atlas 2005, Vol. 4: Nutrients (phosphate, nitrate, silicate) (ed. by S. Levitus). US Government Printing Office, Washington, DC.

Genin, A. \& Dower, J.F. (2007) Seamount plankton dynamics. Seamounts: ecology, fisheries and conservation (ed. by T.J. Pitcher, T. Morato, P.J.B. Hart, M.R. Clark, N. Haggan and R.S. Santos), pp. 85-100. Blackwell Publishing, Oxford.

Genin, A., Dayton, P.K., Lonsdale, P.F. \& Spiess, F.N. (1986) Corals on seamount peaks provide evidence of current acceleration over deep-sea topography. Nature, 322, 59-61.

Gjerde, K.M. (2006) Ecosystems and biodiversity in deep waters and high seas. UNEP Regional Seas Reports and Studies No. 178. UNEP/IUCN, Gland, Switzerland.

Glover, A.G. \& Smith, C.R. (2003) The deep-sea floor ecosystem: current status and prospects of anthropogenic change by the year 2025. Environmental Conservation, 30, 219-241.

Guinotte, J.M., Orr, J., Cairns, S., Freiwald, A., Morgan, L. \& George, R. (2006) Will human induced changes in seawater chemistry alter the distribution of deep-sea scleractinian corals? Frontiers in Ecology and the Environment, 4, 141146.

Guisan, A. \& Zimmermann, N.E. (2000) Predictive habitat distribution models in ecology. Ecological Modelling, 135, 147-186.

Hall-Spencer, J., Rogers, A.D., Davies, J. \& Foggo, A. (2007) Deep-sea coral distribution on seamounts, oceanic islands and continental shelf slope habitats in the Northeast Atlantic. Bulletin of Marine Science, 81, 135-146.

Harley, C.D.G., Smith, K.F. \& Moore, V.L. (2003) Environmental variability and biogeography: the relationship between bathymetric distribution and geographical range size in marine algae and gastropods. Global Ecology and Biogeography, 12, 499-506.

Helly, J.J. \& Levin, L.A. (2004) Global distribution of naturally occurring marine hypoxia on continental margins. Deep-Sea Research I, 51, 1159-1168.
Henry, L.-A. \& Roberts, J.M. (2007) Biodiversity and ecological composition of macrobenthos on cold-water coral mounds and adjacent off-mound habitat in the bathyal Porcupine Seabight, NE Atlantic. Deep Sea Research I, 54, 654-672.

Hirzel, A.H. \& Arlettaz, R. (2003) Modeling habitat suitability for complex species distributions by environmental-distance geometric mean. Environmental Management, 32, 614-623.

Hirzel, A.H., Helfer, V. \& Metral, F. (2001) Assessing habitatsuitability models with a virtual species. Ecological Modelling, 145, 111-121.

Hirzel, A.H., Hausser, J., Chessel, D. \& Perrin, N. (2002) Ecological-niche factor analysis: how to compute habitatsuitability maps without absence data? Ecology, 83, 20272036.

Hirzel, A.H., Le Lay, G., Helfer, V., Randin, C. \& Guisan, A. (2006) Evaluating the ability of habitat suitability models to predict species presences. Ecological Modelling, 199, 142-152.

Hoegh-Guldberg, O., Mumby, P.J., Hooten, A.J., Steneck, R.S., Greenfield, P., Gomez, E., Harvell, C.D., Sale, P.F., Edwards, A.J., Caldeira, K., Knowlton, N., Eakin, C.M., Iglesias-Prieto, R., Muthiga, N., Bradbury, R.H., Dubi, A. \& Hatziolos, M.E. (2007) Coral reefs under rapid climate change and ocean acidification. Science, 318, 1737-1742.

Holland, K.N. \& Grubbs, R.D. (2007) Fish visitors to seamounts: tunas and billfish at seamounts. Seamounts: ecology, fisheries and conservation (ed. by T.J. Pitcher, T. Morato, P.J.B. Hart, M.R. Clark, N. Haggan and R.S. Santos), pp. 189-201. Blackwell Publishing, Oxford.

Jaynes, E.T. (1957) Information theory and statistical mechanics. Physical Review, 106, 620-630.

Key, R.M., Kozyr, A., Sabine, C.L., Lee, K., Wanninkhof, R., Bullister, J.L., Feely, R.A., Millero, F.J., Mordy, C. \& Peng, T.-H. (2004) A global ocean carbon climatology: results from global data analysis project (GLODAP). Global Biogeochemical Cycles, 18, 1-23.

Kitchingman, A. \& Lai, S. (2004) Inferences on potential seamount locations from mid-resolution bathymetric data. Seamounts: biodiversity and fisheries (ed. by T. Morato and D. Pauly), pp. 7-12. UBC Fisheries Centre, Vancouver, BC. Kleypas, J.A., Feely, R.A., Fabry, V.J., Langdon, C., Sabine, C.L. \& Robbins, L.L. (2006) Impacts of ocean acidification on coral reefs and other marine calcifiers: a guide for future research. Report of a Workshop held 18-20 April 2005, St Petersburg, FL. Available at: http://www.ucar.edu/communications/ Final_acidification.pdf (last accessed 4 October 2008).

Koslow, J.A., Gowlett-Holmes, K., Lowry, J.K., O’Hara, T., Poore, G.C.B. \& Williams, A. (2001) Seamount benthic macrofauna off southern Tasmania: community structure and impacts of trawling. Marine Ecology Progress Series, 213, 111-125.

Langdon, C. \& Atkinson, M.J. (2005) Effect of elevated $\mathrm{pCO}_{2}$ on photosynthesis and calcification of corals and interactions with seasonal change in temperature/irradiance and nutrient enrichment. Journal of Geophysical Research, 110, C09S07, doi:10.1029/2004JC002576. 
Laws, E.A., Falkowski, P.G., Smith, W.O. Jr, Ducklow, H. \& McCarthy, J.J. (2000) Temperature effects on export production in the open ocean. Global Biogeochemical Cycles, 14, 1231-1246.

Leclercq, N., Gattuso, J.-P. \& Jaubert, J. (2000) $\mathrm{CO}_{2}$ partial pressure controls the calcification rate of a coral community. Global Change Biology, 6, 329-334.

Locarnini, R.A., Mishonov, A.V., Antonov, J.I., Boyer, T.P. \& Garcia, H.E. (2006) World Ocean Atlas 2005, Vol. 1: Temperature (ed. by S. Levitus). US Government Printing Office, Washington, DC.

Macpherson, E. (2003) Species range size distributions for some marine taxa in the Atlantic Ocean. Effect of latitude and depth. Biological Journal of the Linnean Society, 80, 437455.

Macpherson, E. \& Duarte, C.M. (1994) Patterns in species richness, size, and latitudinal range of East Atlantic fishes. Ecography, 17, 242-248.

Marubini, F. \& Thake, B. (1999) Bicarbonate addition promotes coral growth. Limnology and Oceanography, 44, 716720 .

McClain, C.R. (2007) Seamounts: identity crisis or split personality? Journal of Biogeography, 34, 2001-2008.

O'Hara, T.D. (2007) Seamounts: centres of endemism or species richness for ophiuroids? Global Ecology and Biogeography, 16, 720-732.

O'Hara, T.D., Rowden, A.A. \& Williams, A. (2008) Cold-water coral habitats on seamounts: do they have a specialist fauna? Diversity and distributions, 14, 925-934.

Orr, J.C., Fabry, V.J., Aumont, O., Bopp, L., Doney, S.C., Feely, R.A., Gnanadesikan, A., Gruber, N., Ishida, A., Joos, F., Key, R.M., Lindsay, K., Maier-Reimer, E., Matear, R., Monfray, P., Mouchet, A., Najjar, R.G., Plattner, G.-K., Rodgers, K.B., Sabine, C.L., Sarmiento, J.L., Schlitzer, R., Slater, R.D., Totterdell, I.J., Weirig, M.-F., Yamanaka, Y. \& Yool, A. (2005) Anthropogenic ocean acidification over the twentyfirst century and its impact on calcifying organisms. Nature, 437, 681-686.

Parin, N.V., Mironov, A.N. \& Nesis, K.N. (1997) Biology of the Nazca and Sala y Gómez submarine ridges, an outpost of the Indo-West Pacific fauna in the Eastern Pacific Ocean: composition and distribution of the fauna, its communities and history. Advances in Marine Biology, 32, 145-242.

Pearce, J. \& Ferrier, S. (2000) Evaluating the predictive performance of habitat models developed using logistic regression. Ecological Modelling, 133, 225-245.

Phillips, S.J. \& Dudík, M. (2008) Modeling of species distributions with Maxent: new extensions and a comprehensive evaluation. Ecography, 31, 161-175.

Phillips, S.J., Anderson, R.P. \& Schapire, R.E. (2006) Maximum entropy modeling of species geographic distributions. Ecological Modelling, 190, 231-259.

Renegar, D.A. \& Riegl, B.M. (2005) Effect of nutrient enrichment and elevated $\mathrm{CO}_{2}$ partial pressure on growth rate of Atlantic scleractinian coral Acropora cervicornis. Marine Ecology Progress Series, 293, 69-76.
Rex, M.A., McClain, C.R., Johnson, N.A., Etter, R.J., Allen, J.A., Bouchet, P. \& Warén, A. (2005) A source-sink hypothesis for abyssal biodiversity. The American Naturalist, 165, 163-178.

Rex, M.A., Etter, R.J., Morris, J.S., Crouse, J., McClain, C.R., Johnson, N.A., Stuart, C.T., Deming, J.W., Thies, R. \& Avery, R. (2006) Global bathymetric patterns of standing stock and body size in the deep-sea benthos. Marine Ecology Progress Series, 317, 1-8.

Richer de Forges, B., Koslow, J.A. \& Poore, G.C.B. (2000) Diversity and endemism of the benthic seamount fauna in the southwest Pacific. Nature, 405, 944-947.

Roark, E.B., Guilderson, T.P., Dunbar, R.B. \& Ingram, B.L. (2006) Radiocarbon-based ages and growth rates of Hawaiian deep-sea corals. Marine Ecology Progress Series, 327, 1-14.

Roberts, J., Wheeler, A.J. \& Freiwald, A. (2006) Reefs of the deep: the biology and geology of cold-water coral ecosystems. Science, 312, 543-547.

Rogers, A.D. (1994) The biology of seamounts. Advances in Marine Biology, 30, 305-350.

Rogers, A.D. (1999) The biology of Lophelia pertusa (Linnaeus 1758) and other deep-water reef-forming corals and impacts from human activities. International Review of Hydrobiology, 84, 315-406.

Rogers, A.D., Baco, A., Griffiths, H. \& Hall-Spencer, J.M. (2007) Corals on seamounts. Seamounts: ecology, fisheries and conservation (ed. by T.J. Pitcher, T. Morato, P.J.B. Hart, M.R. Clark, N. Haggan and R.S. Santos), pp. 141-169. Blackwell Publishing, Oxford.

Rogers, A.D., Clark, M.R., Hall-Spencer, J.M. \& Gjerde, K.M. (2008) The science behind the guidelines: a scientific guide to the FAO draft international guidelines (December 2007) for the management of deep-sea fisheries in the high seas and examples of how the guidelines may be practically implemented. IUCN, Gland, Switzerland.

Samadi, S., Bottan, L., Macpherson, E., Richer de Forges, B. \& Boisselier, M.-C. (2006) Seamount endemism questioned by the geographic distribution and population genetic structure of marine invertebrates. Marine Biology, 149, 1463-1475.

Samadi, S., Schlacher, T. \& Richer de Forges, B. (2007) Seamount benthos. Seamounts: ecology, fisheries and conservation (ed. by T.J. Pitcher, T. Morato, P.J.B. Hart, M.R. Clark, N. Haggan and R.S. Santos), pp. 119-140. Blackwell Publishing, Oxford.

Sanders, H.L. (1969) Marine benthic diversity and the stabilitytime hypothesis. Brookhaven Symposia on Biology, 22, 71-81.

Schröder-Ritzrau, A., Freiwald, A. \& Mangini, A. (2005) U/Thdating of deep-water corals from the eastern North Atlantic and the western Mediterranean Sea. Cold-water corals and ecosystems (ed. by A. Freiwald and J.M. Roberts), pp. 157172. Springer-Verlag, Berlin.

Shannon, C.E. (1948) A mathematical theory of communication. Bell System Technical Journal, 27, 379-423, 623-656.

Sissenwine, M.P. \& Mace, P.M. (2007) Can deep water fisheries be managed sustainably? Report and documentation of the 
expert consultation on deep-sea fisheries in the high seas, Bangkok, Thailand, 21-23 November 2006. FAO Fisheries Report No. 838. FAO, Rome.

Sokal, R.R. \& Rohlf, F.J. (1995) Biometry: the principles and practice of statistics in biological research. W.H. Freeman, New York.

Stocks, K.I. \& Hart, P.J.B. (2007) Biogeography and biodiversity of seamounts. Seamounts: ecology, fisheries and conservation (ed. by T.J. Pitcher, T. Morato, P.J.B. Hart, M.R. Clark, N. Haggan and R.S. Santos), pp. 255-281. Blackwell Publishing, Oxford.

Stone, R.P. (2006) Coral habitat in the Aleutian Islands of Alaska: depth distribution, fine-scale species associations, and fisheries interactions. Coral Reefs, 25, 229-238.

Thiem, Ø., Ravagnan, E., Fosså, J.H. \& Berntsen, J. (2006) Food supply mechanisms for cold-water corals along a continental shelf edge. Journal of Marine Systems, 60, 207-219.

Tynan, C.T., Ainley, D.G., Barth, J.A., Cowles, T.J., Pierce, S.D. \& Spear, L.B. (2005) Cetacean distributions relative to ocean processes in the northern Californian Current System. DeepSea Research II, 52, 145-167.

UN General Assembly (2006) Resolution adopted by the General Assembly. 60/30. Oceans and the law of the sea. Available at: http://www.unep.org/dewa/assessments/EcoSystems/water/ MarineAssessment/reports/A-RES-60-30.pdf (last accessed 4 October 2008).

Vinogradova, N.G. (1997) Zoogeography of the abyssal and hadal zones. Advances in Marine Biology, 32, 325-387.

Watson, R., Kitchingham, A. \& Cheung, W.W. (2007) Catches from world seamount fisheries. Seamounts: ecology, fisheries and conservation (ed. by T.J. Pitcher, T. Morato, P.J.B. Hart, M.R. Clark, N. Haggan and R.S. Santos), pp. 400-412. Blackwell Publishing, Oxford.

Wessel, P. (2001) Global distribution of seamounts inferred from gridded Geosat/ERS-1 altimetry. Journal of Geophysical Research, 106, 19,431-19,441.

Wessel, P. (2007) Seamount characteristics. Seamounts: ecology, fisheries and conservation (ed. by T.J. Pitcher, T. Morato,
P.J.B. Hart, M.R. Clark, N. Haggan and R.S. Santos), pp. 3-25. Blackwell Publishing, Oxford.

White, M., Mohn, C., de Stigter, H. \& Mottram, G. (2005) Deep-water coral development as a function of hydrodynamics and surface productivity around the submarine banks of the Rockall Trough, NE Atlantic. Cold-water corals and ecosystems (ed. by A. Freiwald and J.M. Roberts), pp. 503-514. Springer-Verlag, Berlin.

White, M., Bachmachnikov, I., Arístegui, J. \& Martins, A. (2007) Physical processes and seamount productivity. Seamounts: ecology, fisheries and conservation (ed. by T.J. Pitcher, T. Morato, P.J.B. Hart, M.R. Clark, N. Haggan and R.S. Santos), pp. 65-84. Blackwell Publishing, Oxford.

Wiley, E.O., McNyset, K.M., Peterson, A.T., Robins, C.R. \& Stewart, A.M. (2003) Niche modeling and geographic range predictions in the marine environment using a machinelearning algorithm. Oceanography, 16, 120-127.

Worm, B., Lotze, H.K. \& Myers, R.A. (2003) Predator diversity hotspots in the blue ocean. Proceedings of the National Academy of Sciences USA, 100, 9884-9888.

Zeebe, R.E. \& Wolf-Gladrow, D. (2001) $\mathrm{CO}_{2}$ in seawater: equilibrium, kinetics, isotopes. Elsevier, New York.

Zweig, M.H. \& Campbell, G. (1993) Receiver-operating characteristic (ROC) plots - a fundamental evaluation tool in clinical medicine. Clinical Chemistry, 39, 561-577.

\section{BIOSKETCH}

Derek P. Tittensor is a postdoctoral fellow specializing in marine macroecology. He is particularly interested in the effects of scale, sampling and anthropogenic impacts on patterns of marine diversity and distribution.

Editor: Alistair Crame 